\title{
CARBOHYDRATE COMPOSITION IN RELATION TO PASTURE QUALITY
}

R. W. BaILeY

Senior Principal Scientific Officer, Plant Chemistry Division, D.S.I.R., Palmerston North

THE TERM "pasture quality" is a measure of the ability of the pasture to provide the nutritive requirements of the grazing animal. Many plant constituents contribute to this policy but only one group, the carbohydrates, will be considered here. At present probably the only reliable and meaningful method of assessing the relative nutritive value of different pastures is by comparing actual animal production on the pastures growing under identical conditions. Such a method is, of course, unsuitable for the plant breeder during the early stages of a plant breeding programme when he needs to select for quality from a large number of plant progenies. For this reason, it is desirable that quality be defined in more specific terms so that relatively simple tests for it can be devised. Work aimed at such a definition should, of course, be based on material from pastures whose animal potential is being measured at the same time. For this reason, work at Plant Chemistry Division on the possible role of the carbohydrate constituents in contributing to nutritive value has been based largely on material from single variety ryegrass pastures on which growth rate in sheep has been the index of animal production. The present account of how the plant carbohydrate composition of pasture can influence pasture quality will be illustrated with results obtained from these trials.

\section{Weight Gains in Sheep on Ryegrass Pastures}

A series of five grazing trials have been run since 1957 in which ewes and their lambs have been fattened on pure single-strain ryegrass pastures. Results from the first two of these trials were described briefly by Johns ( 1963). In all of the trials, short-rotation ryegrass has given consistently better weight gains than perennial ryegrass (see Figs. 1 and 2; -Rae-et-al.,1963; Table 2, Johns, 1962). In the latter three trials (Rae et al., 1964) Ariki gave similar-weight gains to perennial ryegrass while Italian ryegrass gave the higher weight gains characteristic of short-rotation ryegrass. The first three trials also included grass plus white clover treatments for each ryegrass strain and in each case the clover increased the animal weight gains above that of 
TABLE 1: MEAN ANALYSES OF CARBOHYDRATE FRACTIONSFROM THE THREE RYEGRASS TRIALS

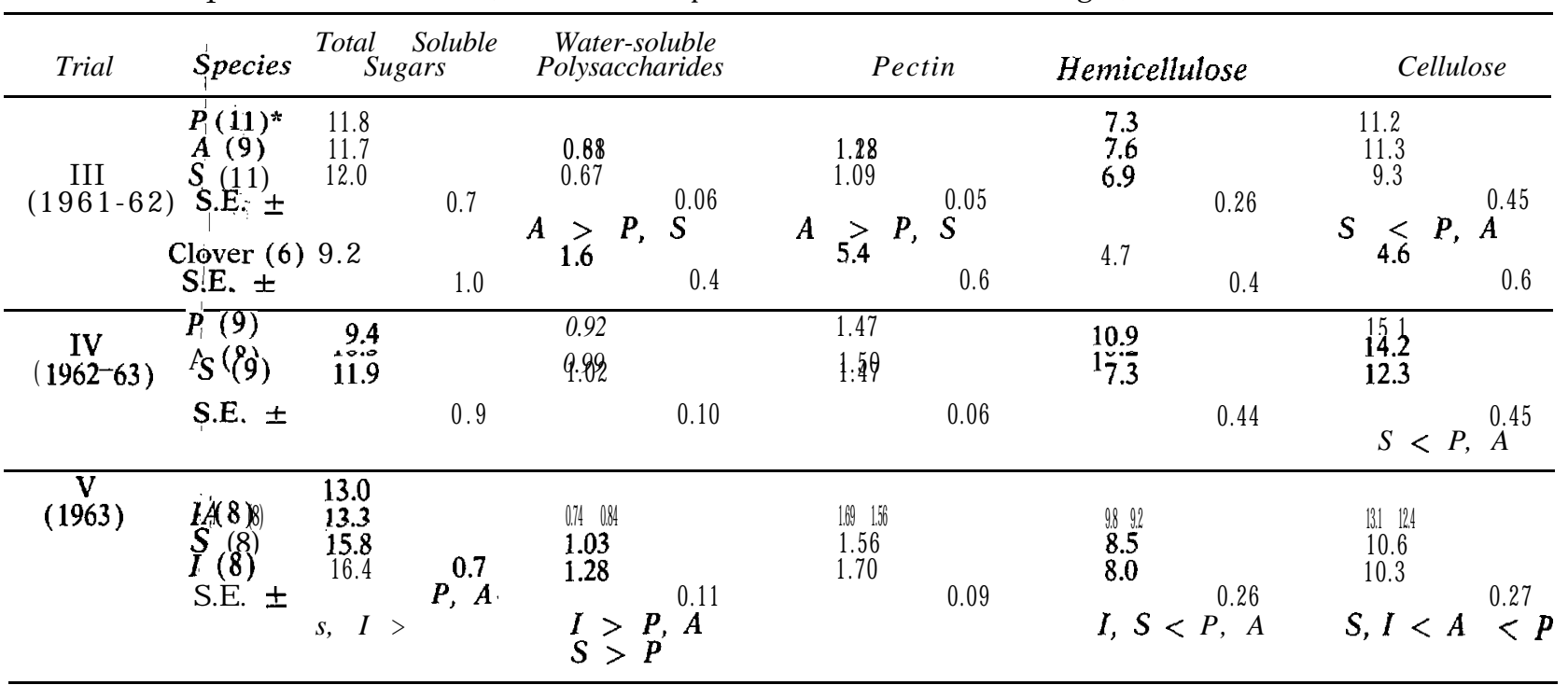

Note: $P=$ perennial, $A=$ Ariki, $\mathrm{S}=$ short-rotation, and $\mathrm{Z}=$ Italian ryegrass.

$>$ means significantly greater than, and < means significantly less than at the $5 \%$ level of probability.

* No. of samples analysed. 
the grass alone but the differential between the ryegrass strains was maintained. Similar grazing trials by MCLean et al. (1962) at Lincoln have also shown better weight gains in sheep on short-rotation as compared with perennial ryegrass pastures

\section{Carbohydrate Composition of Ryegrass from Pastures Giving Different $W$ eight $G$ ains in Sheep}

The results obtained in complete analyses for the various carbohydrate fractions of samples from the ryegrass pastures in the last three Manawatu trials are given in Table 1, together with indications of significant differences; for full experimental details see Bailey (1964). The pastures were also analysed for lignin and total nitrogen.

So far as the ryegrasses are concerned, the important point is that the only significant difference present in all three trials was in cellulose; short-rotation and Italian ryegrass were significantly lower than Ariki and perennial ryegrass. Differences between these two groups of ryegrasses in soluble sugars and hemi-cellulose were detected in only one of the three trials and the levels of water soluble polysaccharide and pectin were probably too low to be of significance to the animals. Other results showed that there was no difference between the grasses in lignin content which was always just above or below $2 \%$. Total nitrogen ranged from 3.3 to $4.3 \%$ with little difference between the grasses except that perennial ryegrass tended to have the highest levels of it.

Before considering the implications of these results, a brief survey of the types of carbohydrate commonly present in pasture grass and clover and of the factors affecting their metabolism in the rumen is necessary.

\section{Carbohydrates of Pasture Plants}

The main carbohydrate constituents of grasses and clovers are classified in Table 2 together with relevant properties.

Mono-, di-, and tri-saccharides are the soluble sugars and fructosan and starch are the water-soluble polysaccharide fractions referred to in Table 1 and the text. The main differences between grasses and clovers are that : (1) Pectin is present in significant amounts in clovers but not in grasses; (2) the soluble reserve polysaccharide in grasses 


\section{Carbohydrates and Pasture Quality}

TABLE 2: CARBOHYDRATE FRACTIONS OF GRASSES AND CLOVERS

\begin{tabular}{|c|c|c|c|}
\hline Carbohydrate & Composition & Plant Function & Solubility \\
\hline $\begin{array}{l}\text { Mono-, di, tri- } \\
\text { saccharides }\end{array}$ & $\begin{array}{l}\text { Mainly } \\
\text { glucose, } \\
\text { fructose and }\end{array}$ & & \\
\hline Fructosan & $\begin{array}{l}\text { sucrose } \\
\text { Fructose } \\
\text { polymer }\end{array}$ & $\begin{array}{l}\text { Soluble } \\
\text { reserve }\end{array}$ & Water soluble \\
\hline Starch & $\begin{array}{l}\text { Glucose } \\
\text { polymer }\end{array}$ & & $\begin{array}{l}\text { Water dispers- } \\
\text { able }\end{array}$ \\
\hline Pectin & $\begin{array}{l}\text { Galacturonic } \\
\text { acid polymer }\end{array}$ & $\begin{array}{l}\text { Cell cement- } \\
\text { ing substance }\end{array}$ & $\begin{array}{l}\text { Cold. dilute acid } \\
\text { solibble }\end{array}$ \\
\hline Hemicellulose & $\begin{array}{l}\text { Complex mix- } \\
\text { ture of poly- } \\
\text { mers of xylose } \\
\text { arabinose, } \\
\text { glucosse, } \\
\text { galactose and } \\
\text { uronic acid }\end{array}$ & Cell walls & $\begin{array}{l}\text { Water insoluble ; } \\
\text { dilute alkali } \\
\text { soluble }\end{array}$ \\
\hline Cellulose & $\begin{array}{l}\text { Glucose } \\
\text { polymer }\end{array}$ & & $\begin{array}{l}\text { Water and dilute } \\
\text { alkali insoluble }\end{array}$ \\
\hline
\end{tabular}

is fructosan and in clovers starch ; and (3) clovers tend to contain less cell wall carbohydrates. The levels of these fractions actually present are dependent on many factors such as climate and, for example, such high levels of fructosan are not encountered in ryegrass grown in the Manawatu as are reported by various workers in Europe.

It is not surprising that these various carbohydrates, with their different solubilities, are fermented in different ways in the rumen. Such differences can be considered from the points of view of two closely related aspects, first, the nature of the end products of fermentation and, second, the rate of fermentation.

\section{End Products of Fermentation}

Different species of rumen bacteria and urotozoa ferment different plant carbohydrate fractions ultimately to mixtures of the three main steam-volatile fatty acids (V.F.A.), acetic, propionic and butyric acids (see Oxford ( 1964) for a classification of rumen micro-organisisms in terms of carbo= hydrates fermented). In brief, cellulose and hemicellulose fermentation favours a predominance of acetic acid, while the fermentation of soluble sugars, fructosan and starch favours a relatively higher proportion of propionic and butyric acid; pectin fermentation leads to acetic and propionic acid formation. 
Studies by Blaxter (1962) and others have shown that, above maintenance, the efficiency of utilization of the energy of these acids is acetic, $33 \%$; propionic, $55 \%$; and butyric, $62 \%$ (glucose is $70 \%$ ). It is evident, therefore, that feeds rich in the more soluble carbohydrates will favour the production of a V.F.A. mixture relatively higher in propionic and butyric acids which is better for the growing animal than that provided by feed high in cellulose and hemicellulose. In addition, acetate is important in fat synthesis and propionate in protein synthesis.

\section{Rate of Fermentation}

The rate of fermentation is important in determining the appetite of the animal. Thus, the more rapidly food is fermented the sooner will the residue pass out of the rumen, and the quicker this rate of passage the more frequent will be the intake of fresh food (see Blaxter, 1962). The residue passing out of the rumen can indude plant particles which have been broken down to a size small enough to pass through the reticulo-omasal orifice. Such particles may contain unfermented cellulose and hemicellulose.

Rates of fermentation of various carbohydrates depend on their accessibility to microbial enzymes in the rumen. In general, soluble carbohydrates are rapidly fermented once the plant cells have burst, while the insoluble cell wall carbohydrates are only slowly fermented.

Release of soluble constituents from plant cells is fairly rapid; thus, studies at the Plant Chemistry Division have shown that, depending on the stage of growth of the plant, up to $60 \%$ of these constituents may be released from clover during the initial chewing (Bryant, 1964). After this breakup of the herbage by maceration, the carbohydrates are fermented at different rates as summarized in Table 3. Some results illustrating the actual rates of breakdown of the ingested carbohydrate fractions, obtained from cows fed on fresh red clover, are also included in the table.

The overall effect of these different rates of fermentation is that the various carbohydrate fractions have different effects on the rate of passage of the feed and hence on the rate of intake. In general, these effects will mean that in a given time the animal will consume more of a more digestible feed (Johns, 1963). 
TABLE 3: FERMENTATION RATES OF PLANT CARBOHYDRATES

\begin{tabular}{|c|c|c|c|}
\hline Carbohydrate & $\begin{array}{c}\text { Relative } \\
\text { Fermentation } \\
\text { Rates }\end{array}$ & $\begin{array}{r}\text { Fermentation } \\
\text { Ingeste } \\
\% \\
\text { (a) end of } \\
2 \mathrm{hr} \text { feed }\end{array}$ & $\begin{array}{l}\text { f Carbohydrate in } \\
\text { d Clover" } \\
\text { loss at } \\
\text { (b) } 3 \mathrm{hr} \text { after } \\
\text { end of feed }\end{array}$ \\
\hline $\begin{array}{l}\text { Soluble sugars } \\
\text { Fructosan }\end{array}$ & Very fast & 80 & 100 \\
\hline $\begin{array}{l}\text { Starch } \\
\text { Pectin }\end{array}$ & Rapid & 50 & $\begin{array}{l}71 \\
35\end{array}$ \\
\hline $\begin{array}{l}\text { Hemicellulose } \\
\text { Cellulose }\end{array}$ & $\begin{array}{l}\text { Slow, may be } \\
\text { hindered by } \\
\text { lignin }\end{array}$ & $\begin{array}{l}0 \\
0\end{array}$ & $\begin{array}{l}22 \\
15\end{array}$ \\
\hline \multicolumn{4}{|c|}{$\begin{array}{l}\text { * These results are means of those obtained from a pair of identical } \\
\text { twin cows fed on fresh red clover. }\end{array}$} \\
\hline
\end{tabular}

\section{Carbohydrate Fractions and the Animal Weight Gains on Ryegrass}

As significant differences between the ryegrasses in soluble carbohydrates were present in only one out of three of the trials, it seems unlikely that, in these trials, the main effect of the ryegrass carbohydrates on the animals was due to effect on the composition of the V.F.A. mixture in the rumen. The major effect of the carbohydrates is more likely to be due to differences in rate of passage which stem from differences in cellulose content. The cellulose is the most slowly fermented carbohydrate fraction and its removal from the rumen via the reticulo-omasal orifice in small plant particles will depend on the rate of breakdown to these particles; this rate is also likely to be slower with higher cellulose tissues. On this reasoning, Ariki and perennial ryegrasses would have the slower rate of passage and hence a lower intake of food.

Of significance in this interpretation are the results from one of the earlier trials in which the sheep were slaughtered immediately on removal from the pastures and their total rumen contents measured. Animals from the short-rotation pastures, though gaining weight at a faster rate, were found to have less rumen_contents,_suggesting_a faster rate of passage, than animals from the perennial pastures (Johns et al., 1963). Other important supporting evidence comes from studies by Evans (1964) on the leaf strength of these ryegrasses. Using material taken at the same time as the samples for carbohydrate analyses, he found that the order of breaking strength was $\mathrm{Z} \& \mathrm{~S}<A<P$ with a significant 
correlation with cellulose content - i.e., the higher the cellulose, the higher the leaf strength.

All of this evidence supports the hypothesis that, in the present trials, a lower rate of passage due to higher cellulose, because of slower passage of cellulose out of the rumen, lowers intake in animals on perennial and Ariki ryegrasses as compared with short-rotation and Italian ryegrasses. It is of some interest to note that the hemicellulose fraction closely associated with cellulose in plants does not give the same consistent differences between the grasses.

Feed quality is often considered to be a function of the protein and lignin contents of the feeds. In the present work, there were no differences between the ryegrasses in lignin levels which were probably too low to have much effect in the animal. Likewise, there were no marked differences in total nitrogen and in any case perennial, with the lowest weight gains, tended to have the highest total nitrogen.

The presence of white clover in all of the pasture types raised all of the animal weight gains; while this effect was probably nothing new, it provides an example of a carbohydrate effect which is probably due predominantly to an effect on V.F.A. composition in the rumen. The mean clover results (from samples of clover from all grass plus clover pastures at several sampling times) are also given in Table 3 and show that the clover carbohydrate composition is quite different from the ryegrasses with a much higher proportion of soluble carbohydrates. Thus, the ratio of soluble sugars + water soluble polysaccharide + pectin to hemicellulose + cellulose is 1.58 for the clover and 0.78 for all of the ryegrass samples. The clover in grass plus clover pastures should, therefore, improve the V.F.A. composition in the rumen and also by virtue of its more rapid fermentation give a faster rate of passage. Johns et al. ( 1963) did, in fact, find that at slaughter animals from short-rotation plus clover pastures (with the highest weight gains ) had a V.F.A. mixture in their rumens with a higher proportion of propionic + butyric acids as compared with animals from the perennial ryegrass only pastures (lowest weight gains).

The parentage of short-rotation ryegrass is perennial $\times$ Italian and of A riki is short-rotation $\times$ perennial. The order of relationship of the grasses to Italian and perennial ryegrasses is, therefore, Italian, short-rotation, Ariki, perennial, which follows the order in which the grasses are placed for leaf strength, cellulose content and weight gains. This suggested that a breeding programme designed to investi- 
gate the heritability of cellulose in ryegrass varieties should be well worth while; moreover, cellulose content and particularly leaf strength as an index of cellulose content are factors which can be measured relatively rapidly in large numbers of single plants. Such a breeding programme is now under way in the plant breeding section at Grasslands Division.

The possible relationship of animal weight gains on ryegrass varieties to cellulose levels in the grasses rather than to the more soluble carbohydrates seems of interest. It should be emphasized, however, that the results, which have been quoted to illustrate the possible role of plant carbohydrates in pasture quality, at present apply only to ryegrass varieties and probably only to these varieties maintained as sheep pastures at about 1 to 2 in. grazing height and growing under Manawatu conditions. Under other conditions and in other species, differences in quality may be connected with either specific soluble carbohydrates, the hemicellulose or, for different reasons from the ones given above, to the cellulose. In this latter connection, it is important to note that in milk production cellulose, with its high acetate production, is important in milk fat production and increasing the rate of passage by grinding hay may actually lower milk fat yields.

\section{A cknowledgements}

My experimental results have been obtained from samples from collaborative trials which at some time or another have involved many members of the staffs of Plant Chemistry Division, Grasslands Division, and Applied Mathematics Division of D.S.I.R., and the Sheep Husbandry Department of Massey University of Manawatu. Special thanks are due to P. Evans of Grasslands Division for permission to refer to his leaf strength studies at present in the press.

\section{REFERENCES}

Bailey, R. W., 1964: Carbohydrate composition of ryegrass varieties grown as sheep pastures. N.Z. J. agric. Res., 7: 496.

Blaxter,-K._L., 1962: The Energy Metabolism of Ruminants. Hutchinson, London.

Bryant, A. 'M., 1963: The release of plant cell contents and its relation to' bloat. Proc. N.Z. Soc. Anim. Prod., 24: 57.

Evans, P., 1964: A study of leaf strength in four ryegrass varieties. N.Z. J, agric. Res., 7: 508.

Johns, A. T., 1962: Some aspects of rumen metabolism influencing intake and production in sheep. Proc. N.Z. Soc. Anim. Prod., 22: 88. 
1963: Herbage quality. Proc. 25th N.Z. G rassl. Conf., 59.

Johns, A. T.; Ulyatt, M. J.; Glenday, A. C., 1963: Pasture type in relation to live weight "gain, carcass composition, iodine nutrition and some rumen characteristics of sheep. IV. Some rumen characteristics of sheep. $J$ agric. Sci., 61: 201.

McLean, J. W.; Thomson, G. G.; Iverson, C. E.; Jagusth, K. J.; Lawson, B. M., 1962: Sheep production and health on pure species pastures. Proc. 24th N.Z. G rassl. Conf., 57.

Oxford A. E., 1964: A guide to rumen microbiology. N.Z. Dept. Sci. ind. Res. Bull. 160.

Rae, A. L. ; Brougham, R. W.; Barton, R. A., 1964: A note on liveweight' gains of sheep gräzing different ryegrass pastures. N.Z I. agric. Res., 7: 491.

Rae, A. L. : Brougham R. W.; Glenday A. C.; Butler, G. W., 1963: Pasture type in relation to livewcight gain, carcass composition, iodine nutrition and some rumen characteristics of sheep. I. Live weight growth of the sheep. J. agric. Sci., 61: 187.

\section{DISCUSSION}

At what stage does a digestible cellulose become an indigestible lignin due to encrustation?

Probably somewhere above the 5\% (dry weight) level the lignin levels encountered in the present work were always well below this.

Have any changes in breaking strength of ryegrass leaves in the autumn been noted?

No; however, no real autumn flush has been encountered during the course of the trials.

Are there any figures on the ratio of rumen content to carcass weight on different pasture types?

Values for carcass weight and rumen content for sheep from the various pastures have been published by Johns et al. (1963) — see references above. 